\title{
LEPTOSPIROSIS SEVERITY MAY BE ASSOCIATED WITH THE INTENSITY OF HUMORAL IMMUNE RESPONSE
}

\author{
Regina C.R.M. ABDULKADER(1), Elizabeth F. DAHER(2), Eide D. CAMARGO(3), Cláudia SPINOSA(3) \& Marcos Vinícius da SILVA(4)
}

\begin{abstract}
SUMMARY
Leptospirosis severity may be increasing, with pulmonary involvement becoming more frequent. Does this increase result from an intense immune response to leptospire? Notice that renal failure, thrombocytopenia and pulmonary complications are found during the immune phase. Thirty-five hospitalized patients with Weil's disease had 5 blood samples drawn, from the $15^{\text {th }}$ day to the $12^{\text {th }}$ month of symptoms, for ELISA-IgM, -IgG and -IgA specific antibody detection. According their $1^{\text {st }} \operatorname{IgG}$ titer, the patients were divided into: group $1(n=13)$ titer $>1: 400$ (positive) and group $2(n=22)$ titer $\leq 1: 400$ (negative). Early IgG antibodies in group 1 showed high avidity which may indicate reinfection. Group 1 was older, had worse pulmonary and renal function, and fever for a longer period than group 2. Throughout the study, $\operatorname{IgG}$ and IgA titers remained higher in group 1. In conclusion, the severity of Weil's disease may be associated with the intensity of the humoral immune response to leptospire.
\end{abstract}

KEYWORDS: Leptospirosis; Humoral immune response; Antibody avidity.

\section{INTRODUCTION}

In Brazil, it seems that clinical patterns of Weil's disease have changed; more severe cases are now being detected - mainly with pulmonary involvement ${ }^{5,16}$. In India, the same observation was reported by SINGH et al..$^{20}$. Their study suggests that the pulmonary complications of leptospirosis may have a pathogenesis different from other complications. In a previous retrospective study analyzing 110 patients with Weil's disease hospitalized from 1985 to 1996, we showed that in the 1995-1996 period the frequency of arthralgia, dyspnea, pulmonary rales and dehydration was higher than in the 1985-1993 period $^{5}$. We suggested that those changes could result from an intense immune response consequent to previous leptospira infection as it occurs in dengue hemorrhagic fever ${ }^{11}$.

It is well known that, in leptospirosis, the signs and symptoms of renal and hepatic involvement appear in the immune phase when specific agglutinins begin to be detected ${ }^{10}$. Thrombocytopenia present in this phase has been attributed to immune mechanisms ${ }^{6}$. Could those patients with more intense humoral response have a more severe form of the disease?

\section{PATIENTS AND METHODS}

Patients: Thirty-five patients admitted at Walter Cantídio Universitary Hospital in Fortaleza, CE, from May 1996 to June 1998 with a confirmed diagnosis of leptospirosis were prospectively studied. Leptospirosis diagnosis was suspected by epidemiological and clinical data and confirmed by the presence of specific IgM titer $>1: 400$ in a blood sample collected at about the $15^{\text {th }}$ day after the onset of symptoms. All patients had jaundice and acute renal failure. Acute renal failure was defined as at least one plasma creatinine $\left(\mathrm{P}_{\text {creat }}\right)$ value $>1.5 \mathrm{mg} / \mathrm{dL}$ during hospitalization. The patients were evaluated at hospital admission, throughout the hospitalization and at hospital discharge. The evaluated parameters were: time $(\Delta S)$ from the onset of symptoms to hospital admission, time $(\Delta \mathrm{H})$ of hospitalization, time $(\Delta \mathrm{F})$ of fever (axilar temperature $\geq 37.5^{\circ} \mathrm{C}$ ), time $(\Delta \mathrm{O})$ of oliguria (urinary volume $\leq 600$ $\mathrm{mL} / 24$ hours after hydration $)$, time $\left(\Delta \mathrm{P}_{\text {creat }}\right)$ to normalize $\mathrm{P}_{\text {creat }}(<1.5 \mathrm{mg} /$ $\mathrm{dL})$, time $(\Delta$ Plat $)$ to normalize platelets $\left(\geq 150,000 / \mathrm{mm}^{3}\right)$ and time $(\Delta \mathrm{B})$ for total bilirubin value to reach $1 / 3$ of its maximum value or to normalize $(\leq 0.8 \mathrm{mg} / \mathrm{dL})$. At admission, the following signs and symptoms were also recorded: myalgia, jaundice, dehydration, vomiting, cephalea, arthralgia, hepatomegalia, dyspnea, bloody sputum, cardiac arrhythmia and convulsion. The evaluated laboratory parameters were: (maximum values) leukocytes, bilirubin, hepatic enzymes, creatinekinase, lactic dehydrogenase, $\mathrm{P}_{\text {creat }}$ and proteinuria; (minimum values) hemoglobin, platelets, albumin, arterial partial oxygen pressure while breathing room air, arterial bicarbonate, and plasma sodium and potassium. Also, the need for dialysis and penicillin administration was recorded. Penicillin $(6,000,000$ units/day for 8 days) was prescribed by the assistant infectologist. There is no consensus among the infectious diseases specialists of Walter Cantídio Hospital, or even among the present

(1) Hospital das Clínicas, Serviço/Disciplina de Nefrologia, Faculdade de Medicina, Universidade de São Paulo, São Paulo, SP, Brasil.

(2) Hospital Universitário Walter Cantídio, Departamento de Medicina Clínica, Faculdade de Medicina, Universidade Federal do Ceará, Fortaleza, CE, Brasil.

(3) Seção de Sorologia, Instituto Adolfo Lutz, Secretaria de Saúde do Estado de São Paulo, São Paulo, SP, Brasil.

(4) Instituto de Infectologia Emílio Ribas, Secretaria de Saúde do Estado de São Paulo, São Paulo, SP, and Faculdade de Medicina da Pontifícia Universidade de São Paulo, SP, Brasil.

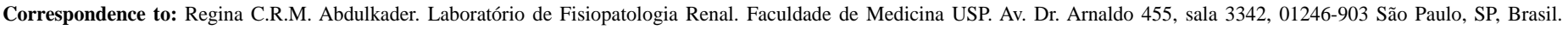

Telephone: 5511 30689428, FAX: 551130831693 email: kader@usp.br 


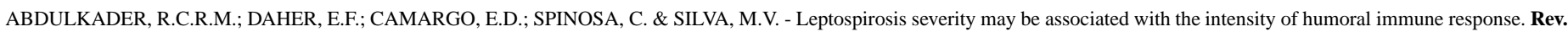
Inst. Med. trop. S. Paulo, 44(2):79-83, 2002.

authors, on the treatment with penicillin: some of them always treat, others never treat and none of them take into account any clinical or laboratory parameter. The patients were divided into 2 groups according to the first IgG titer: group $1(n=13)$ those with $\operatorname{IgG}$ titer $>1: 400$ and group $2(n=22)$ those with $\operatorname{IgG}$ titer $\leq 1: 400$, i. e., negative.

Serological studies: Blood samples were drawn for the serological studies and grouped, according to the onset of symptoms, into: $1^{\text {st }}$ sample $(\mathrm{n}=35)$ drawn $15 \pm 3$ days from the onset of symptoms, $2^{\text {nd }}$ sample $(\mathrm{n}=$ 26) $30 \pm 2$ days, $3^{\text {rd }}$ sample $(n=26) 4 \pm 1$ months, $4^{\text {th }}$ sample $(n=21) 6$ \pm 1 months, $5^{\text {th }}$ sample $(\mathrm{n}=14) 9 \pm 1$ months and $6^{\text {th }}$ sample $(\mathrm{n}=15) 12$ \pm 1 months. At least 2 samples were drawn from thirty-two patients and five of those had all 6 samples drawn. Three patients had only the first sample drawn. Of those three, one died during hospitalization and the other two withdrew from the study prior to the drawing of the $2^{\text {nd }}$ sample. A control negative group, for specific ELISA-IgM, -IgG and -IgA detection, included 32 serum samples drawn from inhabitants of Fortaleza: 22 from normal individuals and 10 from hospitalized patients with lupus eritematosous $(n=2)$, multiple mieloma $(n=1)$, autoimmune hepatitis $(n=1)$, acute glomerulonephritis $(n=1)$, bacterial meningitidis $(\mathrm{n}=1)$, leishmaniasis $(\mathrm{n}=2)$, or tetanus $(\mathrm{n}=2)$. Previously, at admission, a blood sample had been drawn from all thirty-five leptospirosis patients for slide macroagglutination test (SAT, Bio-Manguinhos, FIOCRUZ, RJ, Brazil). Microagglutination test (MAT) was performed on the $1^{\text {st }}$ sample of all patients with leptospirosis and in the second sample of thirty-two using the following serovars: icterohaemorrhagiae, copenhageni, javanica, canicola, castellonis, pyrogenes, cynopteri, autumnalis, shermani, djasiman, australis, pomona, grippotyphosa, wolffi, andamana, tarassovi, panama, butembo, brasiliensis, and hardjo. MAT was considered positive for titers $\geq 1: 100$. The identification of the different classes of specific immmunoglobulins was carried out by ELISA method $^{19}$. The cut-off for each immunoglobulin class was determined by the results of the above described control group and the titers were considered positive when $>$ 1:400 for $\operatorname{IgM},>1: 400$ for $\operatorname{IgG}$ and $>1: 40$ for IgA. The antigen used in ELISA method was obtained from a mixture of the following serovars: brasiliensis, canicola, cynopteri, hebdomadis and icterohaemorrhagiae ${ }^{19}$. For determination of $\operatorname{IgG}$ avidity, the same ELISA method for IgG was repeated twice in the $1^{\text {st }}$ samples of group 1 patients: once washing the wells with buffered $0.85 \%$ saline containing $0.05 \%$ Tween and $6 \mathrm{M}$ urea after the wells had been coated with the antigen preparation and incubated with the samples, and once using all of these procedures except for the addition of urea to the washing solution ${ }^{4}$. The rational for urea treatment is that urea solution breaks the linkage of the antigen with the low-avidity antibody but not the linkage of the antigen with the high-avidity antibody. The ratio, at 1:400 dilution, of the optical density (OD) with (U+) to the OD without (U-) urea was calculated and expressed as a percentage: [U+/U-] x100. SAT was carried out at the Laboratório Central de Saúde Pública, Fortaleza, CE and MAT at the Centro de Controle de Zoonoses, São Paulo, SP. The identification of IgM, IgG and IgA specific antibodies and the IgG avidity determination were both carried out at the Serology Section, Instituto Adolfo Lutz, São Paulo, SP.

Ethics and statistical analysis: The study was approved by the Ethics Committees of both Hospital das Clínicas in São Paulo, SP and Hospital Universitário Walter Cantídio in Fortaleza, CE. All enrolled individuals, i. e., patients with leptospirosis, normal individuals and non leptospirosis patients whose blood samples were used as control group gave their written informed consent. For statistical comparison of the immunoglobulin titers in the 2 groups, the antilog2 of each titer was used: e.g. a titer $=1: 12,800$ was considered in the statistical analysis as $=7\left(2^{-7}=1 / 128\right)$. Statistical analysis of quantitative variables consisted of bivariate analysis with Student's "t" test for variables with normal distribution or Mann-Whitney's test for those with no normal distribution. Gaussian distribution was tested using the Kolmogorov-Smirnov test. Fischer's exact test or Chi-square test were used for comparisons of proportions or qualitative variables (GraphPad Prism software, version $2.01,1996)$. The data are presented as mean \pm SD or percentage. The adopted significance level was $\mathrm{p} \leq 0.05$.

\section{RESULTS}

All but five patients were from Fortaleza, four of these five nondwellers were from group 1 (Fischer's test, $\mathrm{p}=0.05$ ). Thirty patients were men $(86 \%)$, aged 18 to 55 years ( $34 \pm 10$ years), and five were women, aged 32 to 48 years ( $38 \pm 6$ years). There was no significant difference in age between men and women. All of the women resided in Fortaleza. In group 1, all patients were men and in group 2, there were seventeen men and five women (Fischer's test, $\mathrm{p}=0.08$ ). In group 1 , the age was $40 \pm 10$ years and in group 2 , it was $33 \pm 10$ years $(p=0.06)$. SAT was positive in $83 \%$ of the thirty five patients: thirteen from group $1(100 \%)$ and fifteen from group $2(68 \%$, Fischer's test, $\mathrm{p}=0.07)$. MAT was performed in the first sample of all patients and in the second sample of 32 patients: 22 of group 2 and 10 of group 1 . The serovar with the highest frequence of positivity was copenhageni. Serovar copenhageni presented the highest in 7 patients of group 1 and in 14 of group 2. Serovar cynopteri presented the highest titer in 4 patients of group 1 and 3 of group 2, both serovars copenhageni and icterohaemorrhagiae had the same highest titer in 3 patients of group 1 and 2 of group 2. Serovar icterohaemorrhagiae had the highest titer in one patient of group 1 and in 2 of group 2. One of each serovar grippotyphosa, javanica or andamana presented the highest titer in 3 patients of group 2. All but four patients were also positive for serovar icterohaemorrhagiae in at least one of the two samples. No difference in the distribution of serovars with the highest titer was found between the 2 groups (chi-square, $\mathrm{p}=$ $0.19)$. The time from the onset of symptoms to the $1^{\text {st }}$ sample collection was similar in both groups: $14 \pm 4$ days in group 1 and $15 \pm 2$ days in group 2 (Mann-Whitney's test, $\mathrm{p}=0.86$ ); the same occurred with all the other samples. The evolution of $\operatorname{IgM}, \operatorname{IgG}$ and $\operatorname{IgA}$ titers in groups 1 and 2 is presented in Figure 1. As it can be observed, IgM titers throughout the study did not differ in the 2 groups, but IgG titers remained higher in group 1 until the $9^{\text {th }}$ month. Also, IgA titers were higher in group 1 during the $1^{\text {st }}$ month. The ratio $\mathrm{U}+/ \mathrm{U}$ - in the $1^{\text {st }}$ sample of group 1 patients was $98 \pm 14 \%$ (64 to $115 \%$ ). In Figure 2 it is shown the IgG individual values of each sample without and with urea addition. There was no difference between the groups in the percentage of penicillin treated patients: $54 \%$ in group 1 and $50 \%$ in group $2(\mathrm{p}=1.00)$, nor in the percentage of patients requiring dialysis: $54 \%$ in group 1 and $45 \%$ in group $2(\mathrm{p}=0.73)$, nor was there a significant difference in the number of oliguric patients: $23 \%$ in group 1 and $5 \%$ in group 2, $p=0.13$ (Fischer's test was used for all comparisons). Group 1 remained feverish for a longer period ( $5 \pm 5$ versus $2 \pm 1$ days, Mann-Whitney's test, $\mathrm{p}=0.03$ ) but other recovery parameters were similar in both groups (Data not shown). Physical examination at admission showed differences (Fischer's test) between the 2 groups only regarding the presence of dehydration $(100 \%$ in group 1 and $41 \%$ in group $2, \mathrm{p}<0.001)$ and dyspnea $(69 \%$ in 


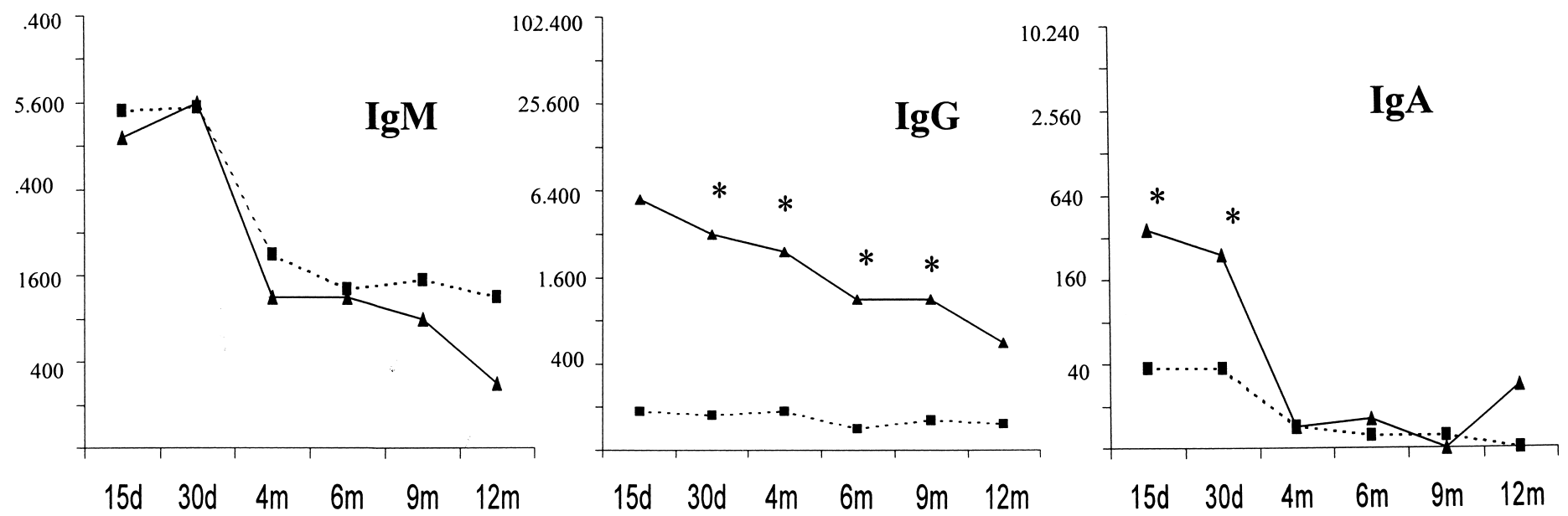

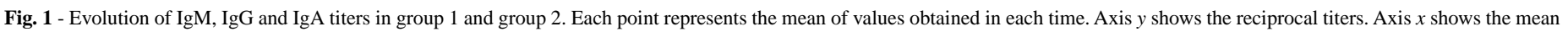
time when the samples were collected. Group 1 is represented as fill triangles and straight lines and group 2 as fill squares and interrupted lines. * $\mathrm{p}<0.05$.

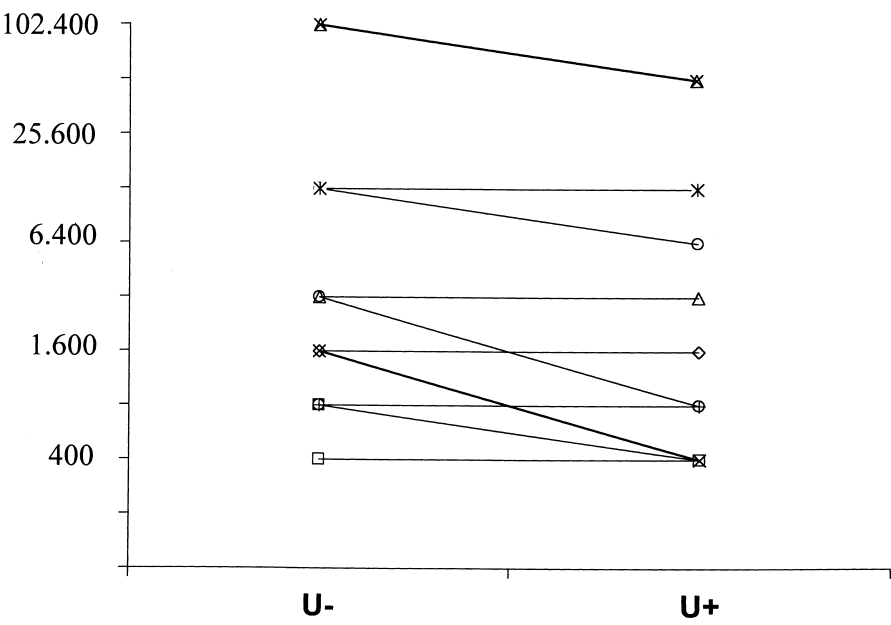

Fig. 2 - Evaluation of IgG affinity in the first sample of group 1 patients. U-: without urea addition. U+: with urea addition. Each symbol represents one patient from group 1. Axis $y$ shows the reciprocal titers.

group 1 and $14 \%$ in group 2, $\mathrm{p}=0.002$ ). Group 1 patients had worse renal and pulmonary function, as shown by the higher levels of plasma creatinine, as well as by the lower levels of arterial blood oxygenation (which is compatible with the more frequent presence of dyspnea in this group) (Tables 1 and 2). Group 1 tended to present lower levels of plasma sodium than group 2: $128 \pm 4$ versus $131 \pm 5 \mathrm{mEq} / \mathrm{L}$ (Student's "t" test, $\mathrm{p}=0.07$ ) (Table 2). No statistical differences were found between the groups in hepatic and haematologic parameters. Only one patient died. He was from group 1 and died from adult respiratory distress syndrome in the $12^{\text {th }}$ day of hospitalization.

\section{DISCUSSION}

Group 1 patients that presented a more intense and lasting immune response also had more severe renal and pulmonary involvement and remained feverish for a longer period. Therefore, two questions arise: 1 .
Table 1

Maximum values of laboratory parameters in groups 1 and 2 during hospitalization

\begin{tabular}{lcc}
\hline & Group $1 \mathrm{n}=13$ & Group $2 \mathrm{n}=22$ \\
\hline${\text { Leukocytes }\left(x 10^{3} / \mathrm{mm}^{3}\right)}$ & $13.2 \pm 3.7$ & $12.4 \pm 6.0$ \\
Bilirubin $(\mathrm{mg} / \mathrm{dL})$ & $25 \pm 11$ & $21 \pm 13$ \\
GOT (IU/L) & $141 \pm 113$ & $100 \pm 63$ \\
$\mathrm{GPT}(\mathrm{IU} / \mathrm{L})$ & $81 \pm 42$ & $72 \pm 49$ \\
$\mathrm{LDH}(\mathrm{IU} / \mathrm{L})^{c}$ & $607 \pm 217$ & $762 \pm 439$ \\
$\mathrm{CK}(\mathrm{IU} / \mathrm{L})^{b}$ & $274 \pm 103$ & $1403 \pm 927$ \\
$\mathrm{P}_{\text {creat }}(\mathrm{mg} / \mathrm{dL})$ & $6.9 \pm 2.5$ & $5.0 \pm 2.6^{a}$ \\
$\mathrm{U}_{\text {prot }} \mathrm{V}(\mathrm{mg} / 24$ hours $)$ & $736 \pm 125$ & $673 \pm 119$ \\
\hline
\end{tabular}

Data are presented as mean $\pm 1 S D$; GOT: Glutamic oxalacetic transaminase; GPT:Glutamic piruvic transaminase; LDH: Lactic dehydrogenase; CK: Creatinekinase; $\mathrm{P}_{\text {creat }}$ : Plasma creatinine; $\mathrm{U}_{\text {prot }} \mathrm{V}$ : Proteinuria; ${ }^{a} \mathrm{p}=0.04$ versus group $1 ;{ }^{b}$ In group $1 \mathrm{n}=11$, in group $2 \mathrm{n}=20 ;{ }^{c}$ In group $2 \mathrm{n}=21$

Table 2

Minimum values of electrolytes, hemoglobin, platelets, albumin and arterial blood oxigenation in groups 1 and 2 during hospitalization

\begin{tabular}{lcc}
\hline & Group $1 \mathrm{n}=13$ & Group $2 \mathrm{n}=22$ \\
\hline Hemoglobin $(\mathrm{g} / \mathrm{dL})$ & $10.8 \pm 1.4$ & $10.8 \pm 1.6$ \\
${\text { Platelets }\left(\mathrm{x} \mathrm{10} / \mathrm{mm}^{3}\right)}_{\text {Albumin }(\mathrm{g} / \mathrm{dL})^{c}}$ & $58 \pm 42$ & $67 \pm 51$ \\
$\mathrm{PaO}_{2}(\mathrm{~mm} \mathrm{Hg})^{d}$ & $2.6 \pm 0.6$ & $3.0 \pm 0.8$ \\
$\mathrm{Bicarbonate}(\mathrm{mEq} / \mathrm{L})$ & $85 \pm 13$ & $96 \pm 14^{a}$ \\
$\mathrm{P}_{\mathrm{Na}}(\mathrm{mEq} / \mathrm{L})$ & $20 \pm 3$ & $21 \pm 5$ \\
$\mathrm{P}_{\mathrm{K}}(\mathrm{mEq} / \mathrm{L})$ & $128 \pm 4$ & $131 \pm 5^{b}$ \\
\hline
\end{tabular}

Data are presented as mean $\pm 1 S D ; \mathrm{PaO}_{2}$ : Arterial oxigen partial pressure while breathing room air; $\mathrm{P}_{\mathrm{Na}}$ : Plasma sodium; $\mathrm{P}_{\mathrm{K}}$ : Plasma potassium; ${ }^{a} \mathrm{p}=0.02$ versus group $1 ;{ }^{b} \mathrm{p}=0.07$ versus group $1 ;{ }^{c}$ In group $2 \mathrm{n}=18 ;{ }^{d} \operatorname{In}$ group $1 \mathrm{n}=12$. 
why did group 1 patients have this intense and long lasting humoral response? and 2. how can an intense immune response intensify the severity of leptospirosis since it is known that $\operatorname{IgG}$ antibodies are protective?

Specific humoral response in leptospira infection is characterized by IgM antibodies detection beginning on the $3^{\text {rd }}$ day of symptoms, and, from the second week on, also by IgG antibodies detection ${ }^{1,19,22}$. IgA specific antibodies are usually detected from the $5^{\text {th }}$ day up to the $9^{\text {th }}$ month of the infection ${ }^{19}$. But not all patients produce IgG antibodies. The early detection of specific $\operatorname{IgM}$ and $\operatorname{IgG}$ is a general indicator of reinfection in various infectious diseases. A recent study of dengue showed that both $\operatorname{IgM}$ and $\operatorname{IgG}$ are detected early in patients with dengue hemorrhagic fever, but only later in patients with nonhemorrhagic dengue $^{3}$. After a primary infection, IgG antibodies initially show lowavidity to the antigen and the antigen-antibody complex is easily disassociated. Later, the avidity to the antigen increases and the antigenantibody complex becomes more stable ${ }^{23}$. In toxoplasma and rubella reinfection, it was shown that the IgG antibodies present early highavidity ${ }^{4,13,15,17}$. Although this behaviour had not been described in leptospirosis, reinfection might be suspected from the early detection of high-avidity specific IgG antibodies concomitant with IgM antibodies as it was found in group 1 .

The humoral immune response of group 1 patients was more intense and had a longer duration than that of group 2. The IgG and IgA titers of group 1 were higher and were sustained for a longer period than those of group 2. The response of IgM antibodies was not statistically different between the two groups. The finding of high $\mathrm{U}+/ \mathrm{U}-$ ratio $(95 \pm 14 \%)$ in the $1^{\text {st }}$ sample of group 1 , drawn on about the $15^{\text {th }}$ day from the onset of symptoms, might indicate the presence of high avidity antibodies, i.e., a secondary humoral response to a reinfection (as occurs in other infectious diseases $)^{3,4,13,15,17}$. For toxoplasma and rubella, U+/U- ratio value $\geq 25 \%$ has been adopted as indicative of high-avidity ${ }^{4,13,17}$. In addition, the finding that on about the $15^{\text {th }}$ day from the symptoms onset all patients of group 1 had positive SAT (compared to only $68 \%$ of group 2 ) also indicates the presence of an immune mechanism trigger in group 1 .

Group 1 patients tended to be older and all were men, both of which reinforce the hypothesis of reinfection. It is known that the prevalence of leptospirosis is higher among men and that the prevalence of positive serology increases with age, probably resulting from more frequent exposition to leptospira ${ }^{8,9}$.

Group 1 patients remained feverish for a longer period. This finding may also indicate a more intense immune response due to previous infection, in analogy with the experimental result that fever was induced by virulent leptospire injection in immunized rabbits, whereas nonimmunized rabbits exhibited no fever after injection ${ }^{10}$.

In trying to answer the $2^{\text {nd }}$ proposed question about intensity of immune response and leptospirosis severity, there are some findings in the literature to be considered. There is a report that among ten dogs with natural acute leptospiral infection and concomitant finding of positive $\operatorname{IgM}$ and $\operatorname{IgG}$ specific antibodies, only two of them survived ${ }^{12}$. The finding of concomitant IgG and IgM presence in acute disease in these dogs suggests either reinfection or a long period elapsed since vaccination. The leptospirosis severity in those dogs could be related to an immune response which was insufficient to protect from the present infection, but still active enough to induce intense inflammatory response.

An intense immune response induces a very high level of inflammatory cytokines (for instance $\mathrm{TNF} \alpha$ ) resulting in severe tissue lesion. TNF $\alpha$ levels in ten patients with acute leptospirosis were measured. Nine of them showed an increased level. The highest level was found in the one with acute renal failure ${ }^{7}$. In another study of eighteen patients with leptospirosis, TNF $\alpha$ was detected in three of those four that died (all with kidney, liver and lung involvement), whereas TNF $\alpha$ was detected in only one patient among the fourteen survivors ${ }^{21}$.

In a recent paper on antibody toxicity in Cryptococcus neoformans infection, it was shown that specific IgG1 administration to infected animals induced acute lethal toxicity. This did not happen with specific $\operatorname{IgM}, \operatorname{IgG} 3$ or IgA administration ${ }^{14}$. These data suggest that the IgG subclass can have a role in determining protection or increasing the severity of the disease. In the present paper, the IgG subclasses were not identified.

It has been reported that increased titers of anticardiolipin antibodies are present in leptospirosis patients with severe complications, but not in those with uncomplicated leptospirosis ${ }^{18}$. This finding suggests that even non-specific humoral immune response could be involved in the severity of the disease.

The possibility that the presence of specific antibodies may worsen cellular lesion is also supported by the experimental finding that the attachment of virulent leptospires to cells is enhanced by subagglutinating amounts of homologous antiserum ${ }^{10}$.

The immunity to leptospirosis depends on the immune response of the infected individual and on the virulence of the infecting serovar. Some individuals maintain high titers of $\operatorname{IgG}$ and $\operatorname{IgM}$ antibodies for extended periods of time while others do not even produce IgG antibodies ${ }^{2}$. In the present study we did not intend to isolate leptospira thus it was not possible to identify the infectant serovar. The results of MAT showed that both groups presented similar distribution of serovars. Thus no conclusion about the role of the infectant serovar on the severity of the disease could be taken from our results.

In conclusion, we propose that the severity of Weil's disease can be determined not only by the virulence of the infecting serovar, but also by the intensity of immune response; the more intense and early the immune response, the more severe the disease.

\section{RESUMO}

\section{A gravidade da leptospirose pode estar associada à intensidade da resposta imune humoral}

A gravidade da leptospirose parece estar aumentando principalmente quanto ao envolvimento pulmonar. Essa maior gravidade poderia ser decorrente de uma resposta imunológica mais intensa, já que tanto a insuficiência renal, quanto a plaquetopenia e as lesões pulmonares são encontradas na fase imune da doença. Para investigar esta hipótese foram detectados por ELISA anticorpos IgM, IgG e IgA específicos em amostras de sangue de 35 pacientes internados com síndrome de Weil colhidas a 
partir de cerca de 15 dias do início dos sintomas até 1 ano após a alta. Os pacientes foram divididos em 2 grupos conforme o seu título de $\mathrm{IgG}$ na primeira amostra, colhida com até 2 semanas de sintomas: grupo 1 ( $\mathrm{n}=$ 13) com título $>1: 400$ (positivo) e grupo $2(n=22)$ com título $\leq 1: 400$ (negativo). Os anticorpos IgG no grupo 1 na primeira amostra mostraram alta avidez pelo antígeno o que sugere reinfecção. Mesmo em amostras mais tardias os títulos de IgG e IgA no grupo 1 foram mais elevados que no grupo 2. Os pacientes do grupo 1 eram mais idosos, permaneceram com febre por mais tempo e tiveram maior comprometimento renal e pulmonar. Estes resultados sugerem que a gravidade da leptospirose pode estar associada à intensidade da resposta humoral.

\section{ACKNOWLEDGMENT}

This work was funded by a grant (number: 96/8364-4) from Fundação de Amparo à Pesquisa do Estado de São Paulo (FAPESP).

Partial results were presented at the $2^{\text {nd }}$ Meeting of the International Leptospirosis Society, Marysville, Victoria, Australia, August 22-25, 1999.

The authors are very thankful to Érica Giuseppina B. Chapola, pharmacist of the Centro de Controle de Zoonoses da Prefeitura Municipal de São Paulo, for performing the microagglutination test (MAT).

\section{REFERENCES}

1. ADLER, B.; MURPHY, A.M.; LOCARINI, S.A. \& FAINE, S. - Detection of specific anti-leptospiral immunoglobulins $\mathrm{M}$ and $\mathrm{G}$ in human serum by solid-phase enzymelinked immunosorbent assay. J. clin. Microbiol., 11: 452-457, 1980.

2. ADLER, B. \& FAINE, S. - The antibodies involved in the human immune response to leptospiral infection. J. med. Microbiol., 11: 387-400, 1978.

3. BRANCH, S.L. \& LEVETT, P.N. - Evaluation of four methods for detection of immunoglobulin M antibodies to dengue virus. Clin. diag. Lab. Immunol., 6: 555$557,1999$.

4. CAMARGO, M.E.; DA SILVA, S.M.; LESER, P.G. \& GRANATO, C.H. - Avidez de anticorpos IgG específicos como marcadores de infecção primária recente pelo Toxoplasma gondii. Rev. Inst. Med. trop. S. Paulo, 33: 213-218, 1991.

5. DAHER, E.; ZANETTA, D.M.T.; CAVALCANTE, M.B. \& ABDULKADER, R.C. Risk factors for death and changing patterns in leptospirosis acute renal failure. Amer. J. trop. Med. Hyg., 61: 630-634, 1999.

6. DAVENPORT, A.; RUGMAN, F.P.; DESMOND, M.J. \& GANTA, R. - Is thrombocytopenia in patients with leptospirosis immunologically mediated? J. clin. Path., 42: 439-440, 1989.

7. ESTAVOYER, J.M.; RACDOT, E.; COUETDIC, G.; LEROY, J. \& GROSPERRIN, L. Tumor necrosis factor in patients with leptospirosis. Rev. infect. Dis., 13: 1245$1246,1991$.
8. EVERARD, C.O.R.; EDWARDS, C.N.; EVERARD, J.D. \& CARRINGTON, D.G. - A twelve-year study of leptospirosis on Barbados. Europ. J. Epidem., 11: 311-320, 1995.

9. EVERARD, C.O.R.; EDWARDS, C.N.; WEBB, G.B.; WHITE, H.S.C. \& NICHOLSON, G.D. - The prevalence of severe leptospirosis among humans on Barbados. Trans. roy. Soc. trop. Med. Hyg., 78: 596-603, 1984.

10. FAINE, S.; ADLER, B.; PEROLAT, P. \& BOLIN, C. - Leptospira and leptospirosis. 2. ed. Melbourne, MediSci, 1999.

11. HALSTEAD S.-B. - Pathogenesis of dengue: challenges to molecular biology. Science, 239: 476-481, 1988.

12. HARTMAN, E.G.; VAN DEN INGH, T.S.G.A.M. \& ROTHUIZEN, J. - Clinical, pathological and serological features of spontaneous canine leptospirosis. An evaluation of the IgM- and IgG-specific ELISA. Vet. Immunol. Immunopath.,13: 261-271, 1986.

13. HEDMAN, K.; LAPPALAINEN, M.; SEPPAIA, I. \& MAKELA, O. - Recent primary toxoplasma infection indicated by a low avidity of specific IgG. J. infect. Dis., 159. 736-740, 1989.

14. LENDVAI, N. \& CASADEVALL, A. - Monoclonal antibody-mediated toxicity in Cryptococcus neoformans infection: mechanism and relationship to antibody isotype. J. infect. Dis., 180: 791-801, 1999

15. MORGAN-CAPNER, P. \& THOMAS, H.I.J. - Serological distinction between primary rubella and reinfection. Lancet, 1: 1397, 1998.

16. RIOS-GONÇALVES, A.J.; CAPONE, D.; PAZ, N.A. et al. - Leptospirose. Observações sobre as mudanças dos padrões clínicos no Rio de Janeiro após a grande epidemia de 1988. Arq. bras. Med., 64: 389-397, 1990.

17. ROUSSEAU, S. \& HEDMAN, K. - Rubella infection and reinfection distinguished by avidity of IgG. Lancet, 1: 1108-1109, 1998.

18. RUGMAN, F.P.; PINN, G.; PALMER, M.F.; WAITE, M. \& HAY, C.R.M. Anticardiolipin antibodies in leptospirosis. J. clin. Path., 44: 517-519, 1991.

19. SILVA, M.V.; CAMARGO, E.D.; BATISTA, L. et al. - Behaviour of specific IgM, IgG and IgA class antibodies in human leptospirosis during the acute phase and during convalescence. J. trop. Med. Hyg., 98: 268-272, 1995.

20. SINGH, S.S.; VIJAYACHARI, P.; SINHA, A. et al. - Clinical-epidemiological study of hospitalized cases of severe leptospirosis. Indian J. med. Res., 109: 94-99, 1999.

21. TAJIKI, M.H. \& SALOMÃO, R. - Association of plasma levels of tumor necrosis factor $\alpha$ with severity of disease and mortality among patients with leptospirosis. Clin. infect. Dis., 23: 1177-1178, 1996

22. TERPSTRA, W.J.; LIGTHART, G.S. \& SCHOONE, G.J. - ELISA for detection of specific IgM and IgG in human leptospirosis. J. gen. Microbiol., 131: 377-385, 1985.

23. WERBLIN, T.P.; KIM, Y.T.; QUAGLIATA, F. \& SISKIND, G.W. - Studies on the control of antibody synthesis. III. Changes in heterogeneity of antibody affinity during the course of the immune response. Immunology, 24: 477-492, 1973.

Received: 30 May 2001

Accepted: 04 January 2002 